\title{
BIODEGRADASI POLIETILENA MENGGUNAKAN BAKTERI DARI TPA (TEMPAT PEMBUANGAN AKHIR) GUNUNG TUGEL KABUPATEN BANYUMAS
}

\author{
Zusfahair, Puji Lestari, Dian Riana Ningsih, Senny Widyaningsih \\ Program Studi Kimia Jurusan MIPA \\ Fakultas Sains dan Teknik Unsoed Purwokerto
}

\begin{abstract}
Plastic has high potency to become material that much threats human living in this earth, because made from chemical which cannot degraded by microbes in environment. The successful production and marketing of biodegradable plastics will help alleviate the problem of environmental pollution. One of biodegradable plastic that used in our live is polyethylene. This research reveals that local microbes capable to degrading of polyethylene. Biodegradation test was carried out by using bacteria in soil which was obtained from Gunung Tugel disposal center, Banyumas regency. Kind of polyethylene is LDPE (Low Density Polyethylene) which was obtained from Setiakawan Plastic Factory, Kalibogor, Purwokerto formed to thin film. Characterization of the polyethylene used weight loss percentage method, melting point determination and FTIR. Soil bacteria isolated from Gunung Tugel disposal center, Banyumas regency, obtained 5 single colonies, which coded GT. Bacteria isolate which have highest activity in degrading polyethylene was GT 3, with increasing the time of incubation. Weight loss percentage up to $2.33 \%$ in 1 month. Melting point of polyethylene after biodegradation was decreased that initially $210-220{ }^{\circ} \mathrm{C}$ into $210-213$ ${ }^{\circ} \mathrm{C}$. FTIR spectrophotometer result of polyethylene after biodegradation showed intensity for methylene and methyl cluster was decreased.
\end{abstract}

Keywords : biodegradable, polyethylene, bacteria

\section{PENDAHULUAN}

Polimer sintetik telah banyak berjasa dan memberi kemudahan bagi kita dalam menghadapi kehidupan sehari-hari. Salah satu polimer sintetik yang perkembangannya sangat pesat adalah plastik. Kemudahan dan keistimewaan plastik sedikit banyak telah dapat menggantikan bahan-bahan seperti logam dan kayu dalam membantu kehidupan manusia. Sejak ditemukan oleh seorang peneliti dari Amerika Serikat pada tahun 1968 yang bernama John Wesley Hyatt, plastik menjadi primadona bagi dunia industri. Produksinya di seluruh negara lebih dari 100 juta ton per tahunnya dan $40 \%$-nya dibuang dengan cara ditimbun tanah (Hadi, 2003).
Penggunaan plastik disamping memberikan dampak positif juga memberikan dampak negatif. Plastik sangat berpotensi menjadi material yang mengancam kelangsungan makhluk hidup di bumi ini, karena terbuat dari bahan kimia yang tidak dapat terdegradasi oleh mikroba di lingkungan. Bahan-bahan tersebut tidak dapat dirombak, dihancurkan atau diuraikan oleh mikroba. Limbah plastik yang melimpah saat ini kebanyakan diatasi dengan dibakar dan didaur ulang, akan tetapi pembakaran limbah plastik itu malah berdampak lain, yaitu tercemarnya udara oleh gas-gas hasil pembakaran plastik, di antaranya $\mathrm{CO}_{2}$ dan CO. Di sisi lain pendaur-ulangan hanya mampu menangani sekitar $25 \%$ 
sampah plastik. Salah satu cara mengatasi limbah plastik adalah membuat plastik biodegradabel (plastik yang dapat diuraikan oleh mikroba). Sepuluh tahun terakhir, plastik biodegradabel telah dipasarkan ke masyarakat. Contoh plastik biodegradabel yang digunakan dalam kehidupan kita adalah polietilena. Beberapa mikroba yang diketahui dapat mendegradasi polietilena adalah Pseudomonas sp., Aspergillus niger dan A. glaucus (Kathiresan, 2003).

Salah satu sumber yang paling potensial ditemukannya bakteri-bakteri lokal pendegradasi polimer sintetik yaitu Tempat Pembuangan Akhir (TPA). Daerah tersebut banyak sampah, baik sampah organik yang lama tertimbun dan menjadi busuk maupun sampah anorganik yang tidak bisa busuk, antara lain plastik. Salah satu TPA yang ada Kabupaten Banyumas adalah TPA Gunung Tugel. TPA ini terletak di Desa Kedungrandu Kecamatan Patikraja, dengan area seluas 5 hektar.

$$
\text { Sejauh ini penelitian }
$$

biodegradasi polimer atau senyawa organik lainnya menggunakan mikroba atau bakteri yang sudah diketahui genusnya, oleh karena itu pada penelitian kali ini akan mengeksplorasi bakteri-bakteri lokal dari TPA Gunung Tugel Kabupaten Banyumas yang mempunyai potensi mendegradasi polimer sintetik yaitu polietilena.

\section{METODE PENELITIAN}

\section{Bahan dan Alat}

Bahan-bahan yang digunakan dalam penelitian ini adalah sampel tanah dari TPA Gunung Tugel Kabupaten Banyumas, biji LDPE (Low Density Polyethylene) HANWA dari Pabrik Plastik Setiakawan Kalibogor Purwokerto, medium Nutrient Agar (NA), medium Nutrient Broth (NB), etanol 70\%, akuades, dan pelarut xylena. Alat yang digunakan meliputi alat-alat gelas, termometer, $\mathrm{pH}$ kertas, plastik wrapping, kapas, jarum ose, drugalsky, autoklaf, shaker incubator, kompor listrik, sentrifuge, pembakar bunsen, pipet ukur, alat spektrofotometer FTIR, alat penentu titik leleh, neraca elektronik.

\section{Pengambilan Sampel}

Pengambilan sampel dilakukan pada tanah yang busuk dan terdapat timbunan sampah plastik yang cukup lama. Sampel dimasukkan ke dalam botol yang telah disterilkan. Suhu dan $\mathrm{pH}$ tanah diukur secara in situ.

\section{Isolasi Bakteri Pendegradasi Polietilena}

Sebanyak \pm 1 gram sampel tanah dimasukkan ke dalam $20 \mathrm{~mL}$ medium NB steril, kemudian dikocok pada suhu dan $\mathrm{pH}$ asal selama minimal $1 \times 24$ jam dalam shaker incubator. Larutan pada bagian atas diambil menggunakan pipet mikro sebanyak $\pm 0,1 \mathrm{~mL}$ dan diratakan menggunakan drugalsky ke dalam medium NA pada cawan petri. Campuran medium NA dan larutan bakteri diinkubasi selama minimum 1x24 jam pada suhu asal.

Koloni tunggal diperoleh dengan cara memindahkan koloni yang telah tumbuh di medium NA secara streak quadran (digoreskan dengan pola segi empat atau lebih) ke cawan petri lain menggunakan jarum ose.

\section{Pembuatan Film Tipis Polietilena}

Film tipis polietilena dibuat dengan membuat larutan polietilena $\pm 0,5 \mathrm{~g}$ dalam pelarut xylena sebanyak $15 \mathrm{~mL}$, kemudian dicetak ke dalam cetakan kaca yang berukuran $1,5 \mathrm{~cm} \mathrm{x}$ $1,5 \mathrm{~cm}$. Film tipis polietilena yang telah terbentuk dikarakterisasi dan ditimbang 
terlebih dulu sebelum digunakan untuk biodegradasi.

\section{Skrining Awal Bakteri Pendegradasi Polietilena}

Skrining dilakukan dengan pembuatan larutan bakteri terlebih dahulu. Koloni tunggal yang sudah didapatkan, diinokulasi ke dalam medium NB dan diinkubasi selama 1x24 jam pada suhu asal. Larutan bakteri dalam medium NB diambil menggunakan pipet mikro sebanyak $\pm 0,05 \mathrm{~mL}$ kemudian diratakan menggunakan drugalsky ke dalam medium NA, diinkubasi selama 1x24 jam pada suhu asal.

Film tipis dimasukkan ke dalam medium NA dengan kondisi steril, diinkubasi selama 5 dan 10 hari pada suhu asal. Bakteri yang mampu mendegradasi film tipis, yang ditunjukkan dengan pengurangan bobot film tipis, digunakan untuk uji biodegradasi.

\section{Uji Biodegradasi (Rohaeti dkk, 2004)}

Uji biodegradasi dilakukan dengan variasi waktu selama 5, 10, 15, 20, 25 dan 30 hari pada suhu asal. Film tipis polietilena dimasukkan ke dalam cawan petri yang telah berisi medium NA dan bakteri yang mempunyai kemampuan terbesar dalam mendegradasi polietlena, kemudian diinkubasi sesuai dengan variasi waktu yang telah ditentukan. Proses biodegradasi dihentikan dengan cara membersihkan film tipis polietilena dengan alkohol 70\%, kemudian dicuci beberapa kali dengan aquades, dan polietilena siap dikarakterisasi.

\section{Karakterisasi Polietilena Penentuan Titik Leleh (Hartomo, 1993)}

Titik leleh polietilena ditentukan menggunakan alat penentuan titik leleh.
Sejumlah kristal polietilena dimasukkan ke dalam pipa kapiler sampai tinggi 0,5 $\mathrm{cm}$, kemudian pipa kapiler dipasang pada alat penentuan titik leleh. Data jarak leleh diperoleh saat kristal dalam pipa kapiler mulai meleleh sampai semuanya meleleh.

\section{Penentuan Persentase Kehilangan \\ Bobot (Iswanto dkk, 2002) \\ Penentuan \\ persentase \\ kehilangan bobot ditentukan} berdasarkan penghitungan bobot awal polietilena sebelum uji biodegradasi dan bobot akhir setelah uji biodegradasi.

$\%$ Kehilangan bobot $=$ (bobot awal - bobot akhir) x 100\% bobot awal

\section{Analisis dengan FTIR (Silverstein dkk, 1986)}

Analisis gugus fungsi dilakukan dengan menggunakan spektrofotometer inframerah. Sejumlah kecil polietilena kering $(<1 \mathrm{mg})$ dicampur rata dengan $\pm 100 \mathrm{mg} \mathrm{KBr}$, dipress hingga membentuk pelet, selanjutnya dilakukan analisis menggunakan spektrofotometer FTIR Termo Nicolet Avatar 360 dengan kisaran bilangan gelombang $400-4000$ $\mathrm{cm}^{-1}$

\section{HASIL DAN PEMBAHASAN Isolasi Bakteri Pendegradasi Polietilena}

Bakteri pendegradasi polietilena yang digunakan dalam penelitian diperoleh dari sampel tanah Tempat Pembuangan Akhir (TPA) Gunung Tugel Kabupaten Banyumas. Lokasi pengambilan sampel yaitu pada tanah yang busuk dan terdapat timbunan plastik yang cukup lama. Sampel yang diambil dimasukkan ke dalam botol kaca yang telah disterilkan. Sampel diinokulasikan ke dalam medium cair Nutrient Broth (NB). Isolasi dilakukan 
dengan cara menggoreskan larutan bakteri yang diperoleh pada permukaan medium padat NA dan diinkubasi pada suhu dan $\mathrm{pH}$ asal yaitu suhu $30^{\circ} \mathrm{C}$ dan pH 7, sampai diperoleh koloni tunggal.

Hasil isolasi diperoleh 5 koloni tunggal dan dikode dengan inisial GT. Profil bakteri-bakteri hasil isolasi dari TPA Gunung Tugel dapat dilihat pada Tabel 1.

Tabel 1.Profil bakteri hasil isolasi dari TPA Gunung Tugel, Kab. Banyumas.

\begin{tabular}{ccc}
\hline Kode & Bentuk & Warna \\
Bakteri & Koloni & Koloni \\
\hline GT 1 & Bulat kecil & Krem \\
GT 2 & Bulat kecil & Krem \\
GT 3 & Bulat kecil & Krem \\
GT 4 & Bulat kecil & Krem \\
GT 5 & Bulat kecil & Krem \\
\hline
\end{tabular}

Keterangan: Betuk dan warna diamati berdasarkan penampakan koloni pada medium NA.

Koloni tunggal yang diperoleh kemudian digunakan untuk uji pendahuluan biodegradasi polietilena atau skrining awal bakteri pendegradasi polietilena.

Skrining awal dilakukan untuk menentukan isolat bakteri yang mampu mendegradasi film tipis polietilena, yaitu dengan memasukkan film tipis polietilena ke dalam medium NA yang telah berisi koloni tunggal. Film tipis dimasukkan ke dalam medium NA dengan keadaan aseptis, yaitu daerah sekitar medium harus steril dari bakteribakteri lain yang dapat mengkontaminasi pertumbuhan koloni tunggal. Hasil skrining awal diperoleh data bahwa semua isolat mampu mendegradasi film tipis polietilena yang ditunjukkan dengan kehilangan bobot film tipis. Data persentase kehilangan bobot dari semua isolat dapat dilihat pada Tabel 2.
Tabel 2. Data persentase kehilangan bobot (skrining awal).

\begin{tabular}{ccc}
\hline \multirow{2}{*}{$\begin{array}{c}\text { Kode } \\
\text { Bakteri }\end{array}$} & \multicolumn{2}{c}{$\begin{array}{c}\text { Persentase kehilangan } \\
\text { bobot pada waktu } \\
\text { inkubasi }\end{array}$} \\
\cline { 2 - 3 } & 5 hari & 10 hari \\
\hline GT 1 & $0,35 \%$ & $0,79 \%$ \\
GT 2 & $0,43 \%$ & $0,94 \%$ \\
GT 3 & $0,46 \%$ & $1,01 \%$ \\
GT 4 & $0,26 \%$ & $0,57 \%$ \\
GT 5 & $0,37 \%$ & $0,81 \%$ \\
\hline
\end{tabular}

Isolat GT 3 mampu mendegradasi film tipis polietilena dengan persentase kehilangan bobot terbesar, sehingga isolat ini digunakan selanjutnya untuk uji biodegradasi dan karakterisasi polietilena.

\section{Biodegradasi Polietilena}

Tahap biodegradasi dilakukan dengan waktu inkubasi 5, 10, 15, 20, 25 dan 30 hari. Variasi waktu dengan rentang 5 hari dilakukan agar bakteri hasil isolasi mampu beradaptasi dengan baik terhadap film tipis polietilena. Secara umum, polimer-polimer alam dan sintetik dapat dimakan oleh mikroba hidup, secara kimia dan secara mekanik. Proses biodegradasi polimer oleh mikroba berhubungan dengan kemampuan mikroba untuk beradaptasi dengan substrat yang baru (Mardiana dkk, 2003).

Karbon merupakan sumber makanan untuk berbagai mikroba, untuk itu medium yang digunakan harus sesedikit mungkin mengandung karbon, sehingga diharapkan pada penelitian ini sumber utama karbon bagi bakteri hasil isolasi adalah polietilena. Pengamatan hasil biodegradasi ditentukan dengan menghitung persentase kehilangan bobot polietilena sesuai dengan variasi waktu yang ditentukan. Penentuan persentase kehilangan bobot ini 
digunakan karena mudah, tidak persentase kehilangan bobot film tipis membutuhkan alat rumit dan khusus dalam biodegradasi suatu polimer. Data polietilena pada isolat GT 3 dapat dilihat dalam Tabel 3.

Tabel 3. Data persentase kehilangan bobot film tipis polietilena.

\begin{tabular}{ccccccc}
\hline Kode & \multicolumn{5}{c}{ Waktu Inkubasi } \\
\cline { 2 - 7 } Bakteri & 5 hari & 10 hari & 15 hari & 20 hari & 25 hari & 30 hari \\
\hline Isolat GT3 & $0,46 \%$ & $1,01 \%$ & $1,48 \%$ & $1,78 \%$ & $2,02 \%$ & $2,33 \%$ \\
\hline
\end{tabular}

Hubungan persentase kehilangan bobot film tipis polietilena pada isolat GT 3 dengan waktu inkubasi dapat dilihat pada Gambar 1.

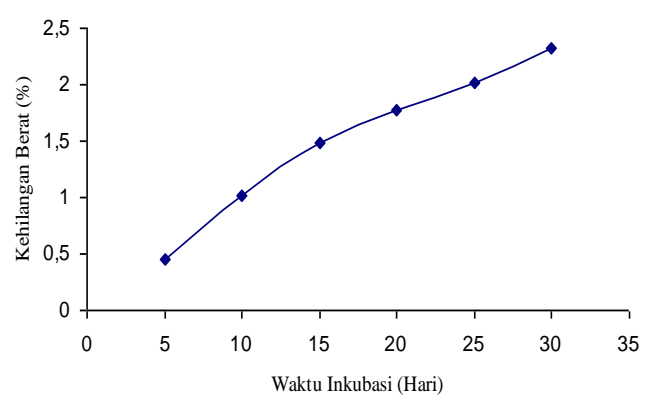

Gambar 1. Persentase kehilangan bobot polietilena isolat GT3

Berdasarkan Gambar 1 persentase kehilangan bobot polietilena isolat GT 3 mengalami peningkatan. Hal ini menunjukkan semakin lama masa inkubasi antara polietilena dengan isolat GT 3 semakin besar pula persentase kehilangan bobot polietilena, dapat disimpulkan bahwa aktivitas bakteri isolat GT 3 semakin meningkat, sehingga bagian polietilena yang terbiodegradasi semakin banyak. Peningkatan persentase kehilangan bobot terhadap waktu inkubasi suatu polimer disebabkan oleh reaksi yang terjadi antara enzim yang dihasilkan oleh bakteri terhadap permukaan polimer, enzim tersebut mengikis permukaan polimer melalui proses hidrolisis, sehingga bobot polimer berkurang dan persentase kehilangan bobot meningkat seiring bertambahnya waktu inkubasi (Bikiaris et.al., 2006). Berdasarkan data persentase kehilangan bobot, bakteri GT 3 memiliki aktivitas paling besar, sehingga bakteri GT 3 diindentifikasi lebih lanjut untuk diketahui genus bakteri.

\section{Identifikasi Isolat GT3}

Identifikasi bakteri pendegradasi polietilena yang diisolasi dari TPA Gunung Tugel Kabupaten Banyumas dilakukan dengan uji morfologi dan aktivitas biokimia. Data hasil uji morfologi isolat bakteri GT 3 dapat dilihat pada Tabel 4.

Tabel 4. Data hasil uji morfologi isolat GT 3

\begin{tabular}{|c|c|c|}
\hline No & Identifikasi & Hasil \\
\hline 1. & $\begin{array}{l}\text { Morfologi } \\
\text { koloni }\end{array}$ & $\begin{array}{l}\text { Koloni kecil, } \\
\text { bentuk teratur tepi } \\
\text { berlekuk, ukuran } \\
\text { kecil, warna } \\
\text { jernih, permukaan } \\
\text { mengkilap, dan } \\
\text { elevasi cembung } \\
\text { rendah. }\end{array}$ \\
\hline 2. & Bentuk sel & $\begin{array}{l}\text { Batang pendek } \\
\text { (cocco bacil) }\end{array}$ \\
\hline 3. & $\begin{array}{l}\text { Pewarnaan } \\
\text { Gram }\end{array}$ & Negatif (-) \\
\hline 4. & $\begin{array}{l}\text { Media } \\
\text { Tumbuh }\end{array}$ & $\begin{array}{l}\text { Nutrient } \\
\text { (NA) }\end{array}$ \\
\hline
\end{tabular}

Aktivitas biokimia setiap jenis bakteri berbeda. Hal ini disebabkan setiap bakteri mempunyai aktivitas 
metabolisme yang berbeda. Pengamatan aktivitas metabolisme diketahui dari kemampuan bakteri untuk menggunakan dan menguraikan molekul yang kompleks. Data hasil uji aktivitas biokimia isolat bakteri GT 3 ditunjukkan pada Tabel 5.

Tabel 5. Data hasil uji aktivitas biokimia isolat GT 3

\begin{tabular}{lll}
\hline No. & Uji & Hasil \\
\hline 1. & Katalase & Positif \\
2. & Oksidase & Negatif \\
3. & Urea & Positif \\
4. & Indol & Negatif \\
5. & Gelatin & Positif \\
6. & Penggunaan & Negatif \\
& Sitrat & \\
7. & Reduksi Nitrat & Positif \\
8. & Asam dari & Glukosa, \\
& karbohidrat (uji & fruktosa \\
& fermentasi) & tanpa gas \\
\hline
\end{tabular}

Hasil uji identifikasi bakteri menunjukkan bahwa bakteri GT 3 yang diisolasi dari TPA Gunung Tugel Kabupaten Banyumas termasuk ke dalam genus Acinetobacter sp.

\section{Karakterisasi Polietilena}

Sampel polietilena dalam bentuk biji dibentuk menjadi film tipis. Film tipis polietilena dibuat dengan melarutkan sejumlah biji polietilena dalam pelarut xylena, yang kemudian dicetak dalam cetakan kaca. Polietilena mempunyai kelarutan yang tinggi di dalam pelarut hidrokarbon, hidrokarbon terhalogenasi, xylena dan dikloroetana pada suhu tinggi (Chang, 2004).

Film tipis polietilena yang telah terbentuk dikarakterisasi dengan menggunakan spektrofotometer FTIR dan ditentukan titik lelehnya. Film tipis polietilena sebelum biodegradasi memiliki kisaran titik leleh $210-220{ }^{\circ} \mathrm{C}$. Kisaran titik leleh yang lebar tersebut menunjukkan adanya bahan tambahan $\begin{array}{lcr}\text { (additive) } & \text { berupa } & \text { stabilisator } \\ \text { pemanasan, } & \text { sehingga } & \text { proses } \\ \text { pelelehannya } & \text { berlangsung } & \text { lama. }\end{array}$ Menurut Suryati (1992), cara memperlambat kerusakan plastik dapat dilakukan dengan jalan pemberian bahan tambahan (additive) berupa antioksidan, stabilisator pemanasan dan stabilisator ultraviolet. Jumlah dan jenis stabilisator yang ditambahkan tergantung dari jenis dan penggunaan produk plastik tersebut. Stabilisator dapat berupa bahan kimia organik atau anorganik, baik senyawa murni ataupun senyawa campuran. Indek leleh dari LDPE sebesar 0,2-30 g/10 menit (Mark, 1971).

Titik leleh film tipis polietilena setelah mengalami biodegradasi berubah menjadi $210-213{ }^{\circ} \mathrm{C}$. Hal ini disebabkan struktur molekul komplek polietilena yang telah terpotong-potong menjadi struktur molekul yang lebih sederhana, sehingga semakin mudah atau cepat untuk meleleh.

Karakterisasi film tipis polietilena sebelum biodegradasi menggunakan spektrofotometer FTIR, diukur pada bilangan gelombang 400$4000 \mathrm{~cm}^{-1}$ supaya spektrum gugus fungsi yang muncul dapat terlihat. Spektrum infra merah polietilena sebelum dan setelah biodegradasi dapat dilihat pada Gambar 2 dan Gambar 3.

Hasil karakterisasi spektrofotometer FTIR polietilena setelah biodegradasi, memperlihatkan perbedaan yang cukup jelas dengan hasil karakterisasi spektrofotometer FTIR polietilena sebelum biodegradasi. Analisis gugus-gugus fungsi polietilena hasil karakterisasi FTIR dapat dilihat pada Tabel 6. 


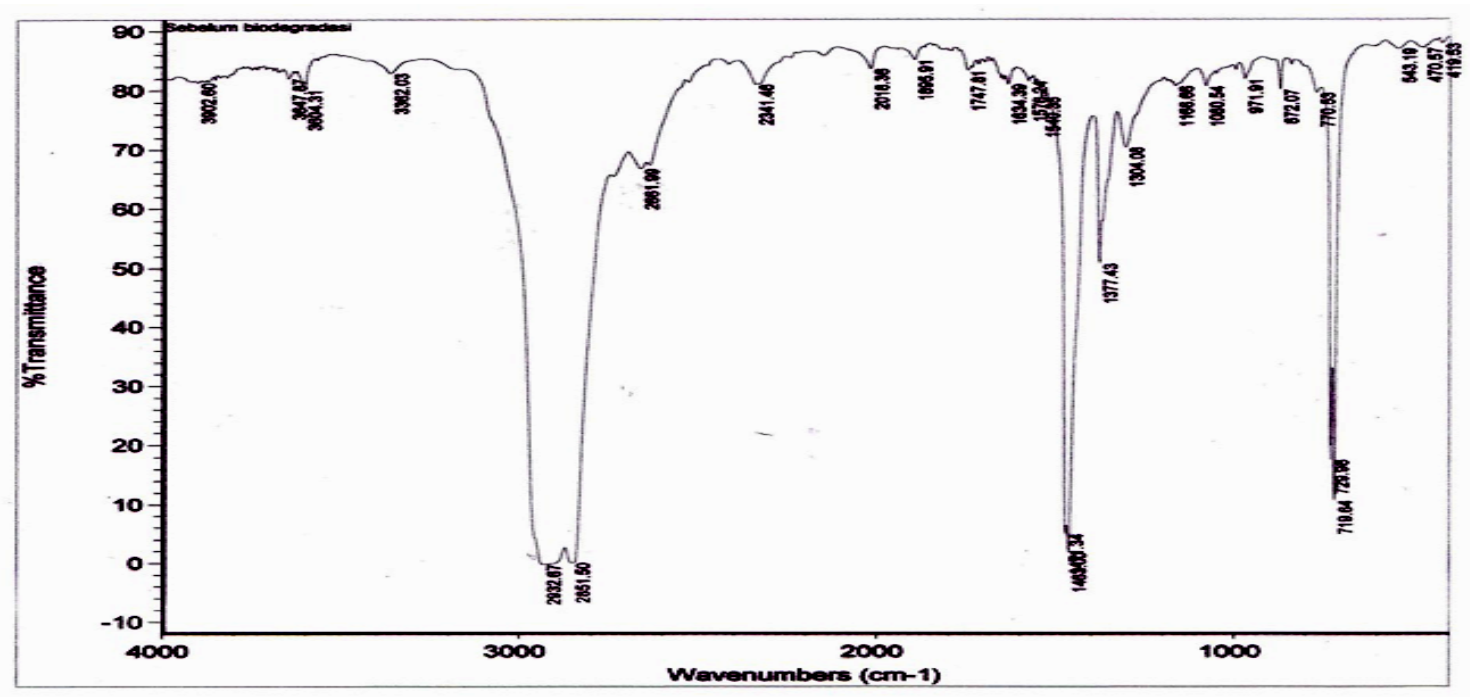

Gambar 2. Spektrum infra merah polietilena sebelum biodegradasi

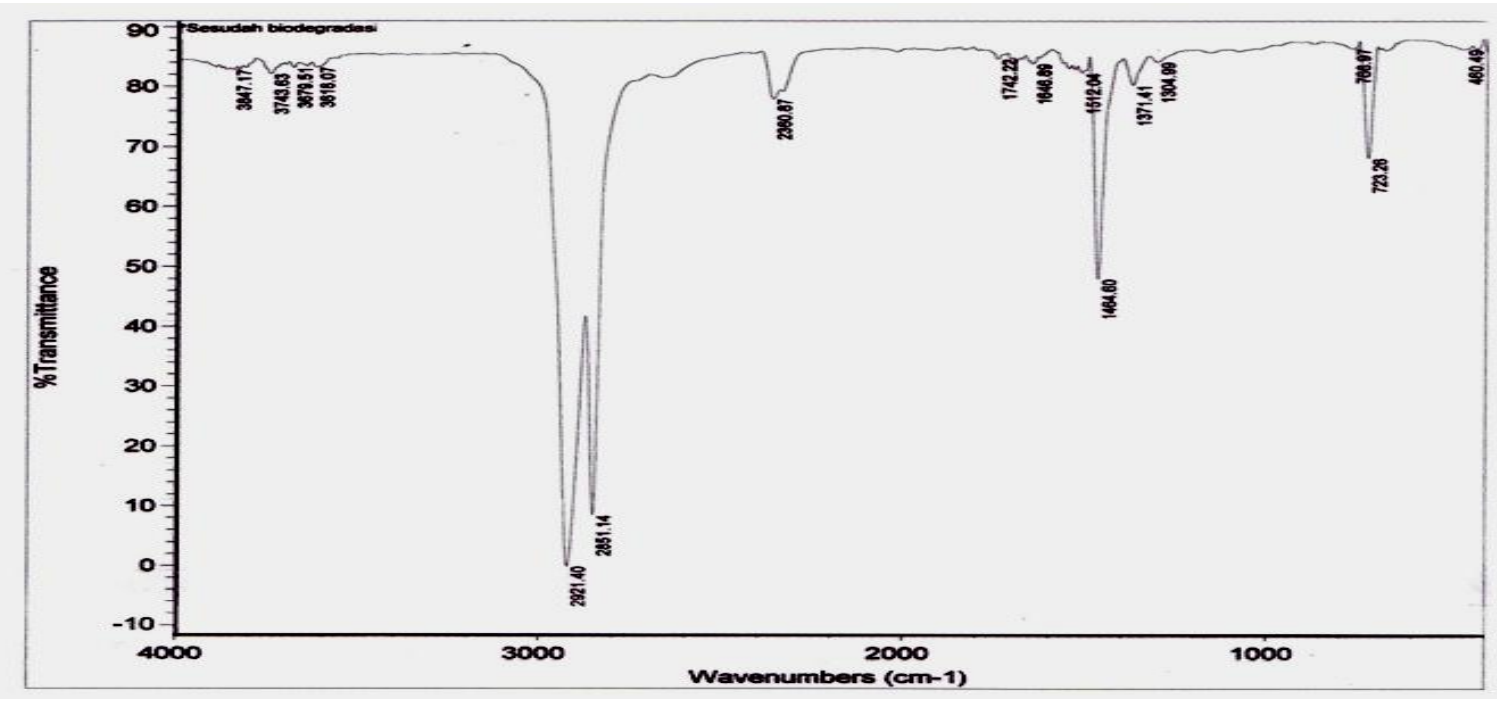

Gambar 3. Spektrum infra merah polietilena setelah biodegradasi

Tabel 6. Analisis gugus fungsi.

\begin{tabular}{lll}
\hline & \multicolumn{1}{c}{ Bilangan gelombang $\left(\mathrm{cm}^{-1}\right)$} & \multicolumn{1}{c}{ Gugus fungsi } \\
\hline \multirow{3}{*}{ Sebelum biodegradasi } & 2932,67 dan 2851,50 & Alifatik $(\mathrm{C}-\mathrm{C})$ \\
& 1463,00 dan 1471,34 & Metilen $\left(\mathrm{CH}_{2}\right)$ \\
& 1377,43 & metil $\left(\mathrm{CH}_{3}\right)$ \\
Setelah biodegradasi & 2921,40 dan 2851,14 & Alifatik $(\mathrm{C}-\mathrm{C})$ \\
& 1464,60 & Metilen $\left(\mathrm{CH}_{2}\right)$ \\
& 1371,41 & metil $\left(\mathrm{CH}_{3}\right)$ \\
\hline
\end{tabular}


Menurut Sastrohamidjojo (1992), adanya gugus metilen dan metil dapat ditentukan dengan menganalisis daerah serapan dari 1465 hingga 1370 $\mathrm{cm}^{-1}$. Puncak tajam pada daerah bilangan gelombang 719,64 dan 729,98 $\mathrm{cm}^{-1}$ yang muncul pada hasil spektrofotometer FTIR polietilena sebelum biodegradasi menunjukkan jenis vibrasi untuk gugus metilen dan metil, yaitu vibrasi goyangan. Serapan goyangan dalam alkana rantai lurus muncul di sekitar $720 \mathrm{~cm}^{-1}$ (Sastrohamidjojo, 1992).

Intensitas pada daerah bilangan gelombang untuk gugus metilen dan gugus metil dalam spektrum polietilena setelah biodegradasi mengalami penurunan. Hal ini menandakan bahwa jumlah rantai polietilena yang mempunyai serapan pada bilangan gelombang tersebut telah berkurang akibat biodegradasi oleh bakteri GT 3 hasil isolasi dari TPA Gunung Tugel Kabupaten Banyumas.

Biodegradasi polietilena relatif lebih cepat dan mudah dibandingkan dengan biodegradasi plastik, karena ketebalan polietilena yang lima kali lebih tipis daripada plastik (Kathiresan, 2003). Biodegradasi terhadap film tipis polietilena oleh bakteri hasil isolasi

\section{DAFTAR PUSTAKA}

Bikiaris, DN., G.Z. Papageorgiou and D.S. Achilias. 2006. Synthesis and Comparative Biodegradability studies of three poly(alkaline succinate)s. Polymer Degradation and Stability. www.elsevier.com/locate/polydeg stab diakses 22Januari08 11:10. dari TPA Gunung Tugel Kabupaten Banyumas, mengakibatkan perubahan secara fisik pada film tipis polietilena. Perubahan secara fisik dapat dilakukan dengan cara melihat secara langsung perubahan yang terjadi pada film tipis polietilena, film tipis sebelum biodegradasi mempunyai sifat yang tidak lentur (kaku) dan tidak mudah sobek. Film tipis polietilena setelah mengalami biodegradasi, polietilena ini menjadi lentur dan mudah sobek.

\section{KESIMPULAN}

1. Genus bakteri hasil isolasi dari TPA Gunung Tugel, Kabupaten Banyumas yang mampu mendegradasi polietilena adalah bakteri Acinetobacter, sp.

2. Hasil biodegradasi menunjukkan persentase kehilangan bobot, titik leleh dan intensitas pada daerah bilangan gelombang gugus metilen dan gugus metil untuk polietilena mengalami penurunan, ini menandakan bahwa jumlah rantai polietilena yang mempunyai serapan pada bilangan gelombang tersebut telah berkurang akibat biodegradasi oleh bakteri GT 3 .

Chang, M. 2004. Polyethylene. Journal of Chemical Engineering of Japan. Vol. 37:1427-1435.

Hadi, S. N. 2003. Anti Sampah Plastik; Ancaman Polimer Sintetik Bagi Kehidupan Manusia. Mahasiswa Program Pasca Sarjana Departemen Biokimia IPB.www.angelfire.com/indie/she foughtbravely/pengetahuan.htm diakses 09Februari07 10:55. 
Kathiresan, K. 2003. Polythene and Plastics-degrading Microbes from the Mangrove Soil. Rev. Biol. Trop 51 (3) : 629-634. www.ucr.ac.cr diakses 07Januari07 09:47.

Mardiana, D., N.M. Surdia, C.L. Radiman, E. Ratnaningsih, A. Rosdiana. 2003 Gliserol : Sumber Monomer Terbaharui dan Pemanfaatannya sebagai Bahan Baku Polimer Ramah Lingkungan. Dalam Prosiding Seminar Sehari 70 tahun Noer Mansdjoeriah Surdia. Departemen kimia Institut Teknologi Bandung. Bandung.

Mark, H.F. 1971. Encyclopedia of Polymer Science and Technology. John Wiley and Sons Inc. New York.

Rohaeti, E., N. M. Surdia, C. L. Radiman dan E. Ratnaningsih. 2004. Pengaruh Dua Macam
Perlakuan Mikroorganisme terhadap Kemudahan Degradasi Poliuretan Hasil Sintesis dari Monomer Polietilen Glikol Berat Molekul 400 dengan Metilen4,4'-difenildiisosianat.

Proceeding ITB Sains \& Teknologi. Vol.36 A, No. 1, 2004, 1-9. $\quad$ http://www.lp.itb.ac.id/ product/ vol36anol/rohaeti.html diakses 7Januari07 09:15.

Sastrohamidjojo, H. 1992. Spektroskopi Inframerah. Liberty Yogyakarta. Yogyakarta.

Silverstein, R.M., G.C. Bassler dan T.C. Morrill. 1986. Penyidikan Spektrometrik Senyawa Organik. Alih bahasa : A.J. Hartomo dan Anny Victor Purba. Edisi ke-4. Erlangga. Jakarta.

Suryati, D. 1992. Penanganan Sampah Plastik. Pusat Dokumentasi dan Informasi Ilmiah LIPI. Jakarta. 